\title{
Polymer blend: a new approach for eliminating curing effect of aqueous dispersion coatings
}

\author{
Nasir Abbas ${ }^{1}$, Muhammad Irfan ${ }^{\circledR 2,3, *}$, Ameer Fawad Zahoor ${ }^{4}$, Ikram Ullah Khan ${ }^{3}$, \\ Haroon Khalid Syed ${ }^{3}$, Akhtar Rasul ${ }^{3}$, Amjad Hussain', \\ Mohammad Sohail Arshad ${ }^{5}$, Noor ul amin Mohsin ${ }^{6}$, \\ Furqan Muhammad Iqbal ${ }^{5}$, Muhammad Abdul Qayyum ${ }^{7}$
}

\begin{abstract}
${ }^{1}$ University College of Pharmacy, University of the Punjab, Lahore, Pakistan, ${ }^{2}$ College of Pharmacy, Freie Universität, Berlin, Germany, ${ }^{3}$ Department of Pharmaceutics, Faculty of Pharmaceutical Sciences, GC University Faisalabad, Faisalabad, Pakistan, ${ }^{4}$ Department of Chemistry, GC University Faisalabad, Faisalabad, Pakistan, ${ }^{5}$ Department of Pharmacy, Bahauddin Zakriya University, Multan, Pakistan, ${ }^{6}$ Department of Pharmaceutical Chemistry, Faculty of Pharmaceutical Sciences, GC University Faisalabad, Faisalabad, Pakistan
\end{abstract}

\begin{abstract}
The aim of present work was to investigate blends of Eudragit ${ }^{\circledR}$ NE 30D with Aquacoat ${ }^{\circledR}$ ECD using different ratios to eliminate curing effect associated with individual polymers. Propranolol $\mathrm{HCl}$ $10 \% \mathrm{w} / \mathrm{w}$ was layered onto sugar cores using 5\% w/w HPMC as a binder. Drug-layered-cores were coated either with pure or blends of Aquacoat ${ }^{\circledR}$ ECD: Eudragit ${ }^{\circledR}$ NE 30D in a fluidized bed coater to obtain $20 \% \mathrm{w} / \mathrm{w}$ coating level. Talc $35 \% \mathrm{w} / \mathrm{w}$ was used as anti-tacking agent. The pellets were characterized for in vitro dissolution studies, morphology, water uptake-weight loss, osmolality and adhesion of coating after curing at $60{ }^{\circ} \mathrm{C}$ or $60{ }^{\circ} \mathrm{C} / 75 \% \mathrm{RH}$ for $24 \mathrm{~h}$. The findings revealed that Aquacoat ${ }^{\circledR}$ ECD coated pellets showed curing effect due to further gradual coalescence of polymeric particles which resulted into better film formation upon curing. In contrast, the curing effect of Eudragit ${ }^{\mathbb{B}}$ NE 30D coated pellets was caused by decrease in adhesion of coatings after curing which provided entirely different swelling behavior of uncured (localized swelling) and cured (uniform swelling) pellets. The undesired curing effect of individual polymers was eliminated by using their blends in appropriate ratio.
\end{abstract}

Keywords: Aqueous dispersion coatings. Polymer blend. Coated pellets. Curing effect. Adhesion.

\section{INTRODUCTION}

Polymeric film coatings are commonly employed onto solid dosage forms (pellets, tablets granules and capsules etc) in order to modify the drug release characteristics (Ho et al., 2009; Muschert et al., 2009a). These widespread film coatings are sprayed onto substrates either from organic polymer solutions or from aqueous polymer dispersions. However, the

*Correspondence: M. Irfan. Department of Pharmaceutics. Faculty of Pharmaceutical Sciences. GC University Faisalabad, Pakistan. Phone: 0092-334-9392369. E-mail: manipharma@yahoo.co.uk application of aqueous polymer dispersions offers numerous advantages over organic polymer solutions such as: less environmental hazards due to avoidance of organic solvent, no flammability concerns and higher solid contents can be coated with aqueous dispersions thus reducing processing time and cost effectiveness (McGinity, Linda, 1997; Fukumori, 1997). But, care has to be taken during coating of aqueous dispersion as the film formation mechanism from these dispersions is complex. Sometimes film is not completely coalesced during coating and further gradual coalescence upon storage leads to unstable release profiles (Shao et al., 2002; Muschert et al., 2009b; Kolter et al., 2013). 
Decrease in drug release (curing effect) upon storage has been reported in literature for commercially available dispersions such as Eudragit ${ }^{\circledR}$ RS and RL 30D, Surelease ${ }^{\circledR}$ and Aquacoat ${ }^{\circledR}$ ECD (Dashevsky et al., 2005; Siepmann et al., 2007). This is due to high minimum film forming temperature (MFT) of these polymers that could cause incomplete coalescence of colloidal polymer particles during coating process.

Different process and formulation parameters (e.g., coating thickness, concentration of polymer and type, and amount of added plasticizer) are varied in order to achieve a desired drug release pattern. However, these variations are often difficult to apply due to not formation of appropriate film and also non-feasibility of processing at large scale. For example, plasticizers added in higher concentrations provide too sticky coatings whereas their lower concentrations result into fragile and brittle films (Siepmann et al., 2005; Siepmann et al., 2008). To overcome such problems, a potential approach is to use the blend of two polymers which are non-toxic and exhibit different physicochemical properties (Dashevsky, Kolter, Bodmeier, 2004; Strübing, Metz, Mäder, 2007). The use of polymer blends helps to provide broad range of drug release patterns by changing the coating properties (Lecomte et al., 2005; El-Malah, Nazzal, 2008). In the case of aqueous polymer dispersions, the use of polymer blends not only helpful in reducing tackiness problems during coating process and storage but it also significantly improves long term stability of coated dosage forms by avoiding unwanted change in drug release profile upon storage (Zheng, McGinity, 2003; Kucera et al., 2008). Additionally, the adhesion of coating to the substrates is improved by adding a second polymer to the coatings which is critical for avoiding curing effect (Felton, McGinity, 1999; Irfan et al., 2009; Irfan et al., 2017).

Eudragit ${ }^{\circledR}$ NE 30D is an ethyl ethacryalte and methyl metharcyalte based aqueous dispersion having a low glass transition temperature $(\mathrm{Tg})-8{ }^{\circ} \mathrm{C}$ and a minimum film forming temperature (MFT) of $5{ }^{\circ} \mathrm{C}$. The films formed by this polymer are highly flexible and soft and therefore no plasticizer addition is recommended for coating process. Despite of its good flexibility, curing effect has been reported in literature with Eudragit ${ }^{\circledR}$ NE 30D coated dosage forms. In contrast, Aquacoat ${ }^{\mathbb{B}}$ ECD is an ethylcellulose based aqueous dispersion with $\mathrm{Tg}$ and MFT of $135{ }^{\circ} \mathrm{C}$ and $75{ }^{\circ} \mathrm{C}$, respectively, which results into extremely brittle films and addition of appropriate plasticizer is necessary before coating.
The stability issues of coated substrates from Aquacoat ${ }^{\mathbb{B}}$ ECD dispersion is also described in literature.

Therefore, the key objectives of this work were to investigate the blends of Eudragit ${ }^{\circledR}$ NE 30D (a polymer having low $\mathrm{T}_{\mathrm{g}}$ ) with Aquacoat ${ }^{\circledR}$ ECD (a polymer with high $\mathrm{T}_{\mathrm{g}}$ ) in different ratios in order to eliminate the curing effect associated with the individual polymers and to develop coating with stable drug release profiles by selecting the appropriate polymer blend ratio.

\section{MATERIAL AND METHODS}

\section{Material}

An aqueous dispersion of ethyl cellulose (Aquacoat ${ }^{\circledR}$ ECD) was donated by FMC, Biopolymers, Brussels, Belgium. Aqueous copolymer dispersion of ethyl acrylate and methyl methacrylate (Eudragit ${ }^{\circledR} \mathrm{NE}$ 30D) was purchased from Evonik, Darmstadt, Germany. Sugar cores $\left(\right.$ Suglets $^{\circledR}$, 710-850 $\mu \mathrm{m}$ ) were generously gifted by NP Pharma, Bazainville, France. propranolol $\mathrm{HCl}\left(\mathrm{C}_{\mathrm{s}}=212 \mathrm{mg} / \mathrm{mL}\right)$ was obtained from BASF, Ludwigshafen, Germany. Talc was purchased from Luzenac Toulouse, France. Colloidal silica (Aerosil $^{\mathbb{R}}$ 200) was gifted by Evonik, Germany and triethyl citrate (TEC) was donated by Morflex, Greensboro, NC, USA.

\section{Drug layering of sugar cores}

The model drug, propranolol $\mathrm{HCl}(10 \% \mathrm{w} / \mathrm{w}$, based on cores), was layered onto sugar cores using hydroxypropyl methycellulose (5\% w/w, based on drug) as a drug binding agent. The drug layering solution was prepared in the mixture of ethanol:water $(60: 40)$ with $15 \% \mathrm{w} / \mathrm{w}$ solids content which was then layered onto sugar cores in a lab scale fluidized bed coater to obtain a $10 \% \mathrm{w} / \mathrm{w}$ drug loading

The drug layering conditions were as follows: batch size $=900 \mathrm{~g}$, inlet temperature $=55^{\circ} \mathrm{C}$, airflow $=100$ $\mathrm{m}^{3} / \mathrm{h}$, product temperature $=40 \pm 2{ }^{\circ} \mathrm{C}$, nozzle diameter $=1.2 \mathrm{~mm}$, atomizing pressure $=1.2 \mathrm{bar}$, spraying rate $=$ $9 \mathrm{~g} / \mathrm{min}$. Finally, the drug-layered-cores were dried at 40 ${ }^{\circ} \mathrm{C}$ for $30 \mathrm{~min}$

\section{Polymer coating of drug-layered cores}

The prepared drug layered cores were coated either with pure Eudragit ${ }^{\mathbb{B}} \mathrm{NE} 30 \mathrm{D}$ and Aquacoat ${ }^{\mathbb{}}{ }^{\mathrm{E}} \mathrm{ECD}$ or with the blends of Aquacoat ${ }^{\circledR}$ ECD: Eudragit ${ }^{\circledR}$ NE 30D (95:5, 
$85: 15,75: 25,60: 40)$ using $15 \% \mathrm{w} / \mathrm{v}$ solids content in a lab scale fluidized bed coater (Mini-Glatt, Glatt $\mathrm{GmbH}$, Binzen, Germany) to obtain $20 \% \mathrm{w} / \mathrm{w}$ coating level (based on solid polymer weight). In order to avoid sticking during coating process, talc $35 \% \mathrm{w} / \mathrm{w}$ (based on solid polymer weight) was added in all investigated coatings. In the case of coating with pure Aquacoat ${ }^{\circledR} \mathrm{ECD}, 25 \% \mathrm{w} / \mathrm{w}$ triethylcitrate (TEC) (based on solid polymer weight) was added to coating dispersion for plasticization whereas no plasticizer was added to Eudragit ${ }^{\circledR}$ NE 30D. Optionally, the pure Aquacoat ${ }^{\circledR}$ ECD was also coated without adding plasticizer. The coating process carried out with following parameters: batch size $=50 \mathrm{~g}$, inlet temperature $=45^{\circ} \mathrm{C}$, product temperature $=38-40{ }^{\circ} \mathrm{C}$, nozzle diameter $=0.5$ $\mathrm{mm}$, airflow $=0.8 \mathrm{~m}^{3} / \mathrm{h}$, atomizing pressure $=0.2 \mathrm{bar}$, maximum spraying rate $=1 \mathrm{~g} / \mathrm{min}$, final drying of coated pellets for $10 \mathrm{~min}$ at $40{ }^{\circ} \mathrm{C}$, (except for pure Eudragit ${ }^{\circledR} \mathrm{NE}$ 30D coatings, the product temperature was adjusted to 18 $\left.{ }^{\circ} \mathrm{C}\right)$. In order to prevent sticking during storage, the coated pellets were shaken manually with approximately $0.5 \%$ $\mathrm{w} / \mathrm{w}$ of colloidal silica. The curing of coated pellets was performed at $60{ }^{\circ} \mathrm{C}$ and $60{ }^{\circ} \mathrm{C} / 75 \% \mathrm{RH}$ for $24 \mathrm{~h}$ following equilibration in a desiccator for $24 \mathrm{~h}$

\section{Water uptake and weight loss of coated pellets}

$500 \mathrm{mg}$ of the both uncured and cured coated pellets were precisely weighed (Initial weight), transferred into $900 \mathrm{~mL}$ of pre-heated $0.01 \mathrm{~N} \mathrm{HCl}$ and stirred at $100 \mathrm{rpm}$ at $37 \pm 0.5{ }^{\circ} \mathrm{C}$ for desired time using USP apparatus II (Vankel Industries, Edison, New Jersy, USA). All samples were run in triplicate. The pellets were collected at pre-defined timer points, filtered and blotted carefully and weighed again (Wet weight). The wet filtered pellets were placed in an oven pre-set at $105{ }^{\circ} \mathrm{C}$ for $4 \mathrm{~h}$ and further equilibrated in a desiccator for $24 \mathrm{~h}$ and weighed again (Dry weight). The water uptake / weight loss were calculated using following formulae: Water uptake (\%) $=($ Wet weight - Dry weight $) /$ Dry weight*100, Weight loss $(\%)=($ Initial weight - Dry weight $) /$ Initial weight $* 100$.

\section{In vitro dissolution studies and swelling of pellets}

Drug release studies were carried out with approximately $500 \pm 5 \mathrm{mg}$ of coated uncured and cured pellets using USP apparatus II (Vankel Industries, New Jersy, USA). $900 \mathrm{~mL} 0.01 \mathrm{~N} \mathrm{HCl}$ was selected as dissolution media at $37 \pm 0.5{ }^{\circ} \mathrm{C}$. The speed of paddles was adjusted at $100 \mathrm{rpm}$ and all samples were run in triplicate. At pre-defined intervals, samples were withdrawn and analyzed on a UV-spectrophotometer (Shimadzu UV-2101PC UV-Vis Shimadzu Europe, Duisburg, Germany).

The behavior of both uncured and cured coated pellets, while conducting dissolution studies, was recorded under a light macroscope using a special software namely image analyzing software (Inteq ${ }^{\circledR}$ Informationtechnik, $\mathrm{GmbH}$, Berlin, Germany). In order to estimate swelling of pellets during dissolution, the diameter of 30 pellets was measured at pre-determined time intervals. Finally, the swelling of pellets was determined using the following formula: Swelling \% = (Wet volume - Dry volume)/Dry volume*100

\section{Morphology of pellets}

In order to observe swelling behaviour during drug release, the pellets approximately $100 \mathrm{mg}$ were placed into $0.01 \mathrm{~N} \mathrm{HCl}$ in a small Petri dish at $37^{\circ} \mathrm{C}$, the pictures were taking after pre-defined intervals with the help of an image capturing software which were also converted into videos. Additionally, the macroscopic pictures of coated uncured and cured pellets before and after drug release studies were captured using a light macroscope.

\section{Determination of adhesive force of coatings}

The model tablets were formulated exactly of same composition like coated pellets and were used to determine the detachment force of the coatings to the drug-layered-cores. For that purpose, the coating of tablets was punch-cut to create a circle of around $7 \mathrm{~mm}$ diameter in the centre. This cut circular part of coating was attached to the metal probe of a TA.XTplus Texture Analyzer (Stable Micro Systems, Godalming, England) with the help of strong adhesive tape. The force at which coating separated from the rest of core was recorded as maximum adhesive force $(n=6)$.

\section{Preparation of free films}

The free films were prepared with the help of a casting knife, using aqueous polymer dispersion exactly of same compositions that were used for the pellet coatings, in small petri dishes. The films were dried at ambient condition, peeled off, packed in air tight polythene bags and stored in desiccator until further use. 


\section{Differential scanning calorimetry (DSC)}

The casted films were used for performing DSC studies with the help of a DSC 821e (Mettler-Toledo $\mathrm{GmbH}$, Gießen, Germany). Samples approximately 8-10 mg were weighed and enclosed in $40 \mu \mathrm{l}$ crucibles pans. DSC thermograms were recorded applying $10 \mathrm{~K} / \mathrm{min}$ heating rate from -20 to $150{ }^{\circ} \mathrm{C}$ for all the investigated films with $80 \mathrm{~mL} / \mathrm{min}$ flow rate of $\mathrm{N} 2$ gas. The computed extrapolated peaks were used to estimate $\mathrm{Tg}$ using the Starw Software (Mettler-Toledo GmbH, Gießen, Germany).

\section{RESULT AND DISCUSSION}

Curing effect (decrease in drug release) is one of the most critical challenges associated with the use of aqueous polymer dispersions for developing oral controlled release dosage forms (tablets, pellets and granules etc) as described in literature (Hudovornik, Vrecer, 2015; Cuppoka et al., 2011; Kranza, Gutsche, 2009). Eudragit ${ }^{\circledR}$ NE 30D is a flexible whereas Aquacoat ${ }^{\circledR}$ ECD is a brittle polymer and curing effect has been reported with both of these polymers, despite of their entirely different mechanical behavior, without providing clear mechanistic understandings. Therefore, this work was an effort to explain what could be the reasons for the curing effect of Eudragit ${ }^{\circledR} \mathrm{NE}$ 30D and Aquacoat ${ }^{\circledR}$ ECD coatings, also if their polymer blend could be a promising approach to eliminate curing effect and to develop formulations with stable release profile.

A clear difference in drug release rates of uncured and cured Eudragit ${ }^{\circledR}$ NE 30D (Figure 1B) and Aquacoat ${ }^{\circledR}$ ECD (Figure 1A) coated pellets showed a strong cured effect which was more profound at elevated temperature and humidity.

The results of supportive studies such as water uptake, weight loss and swelling of Eudragit ${ }^{\circledR} \mathrm{NE}$ 30D and Aquacoat ${ }^{\circledR}$ ECD coated pellets were as follows: for instance, the water uptake and swelling of Aquacoat ${ }^{\circledR}$ ECD coated pellets did not change upon curing (Figure $2 \mathrm{~A}, 2 \mathrm{C}$ ) whereas the weight loss of uncured and cured Aquacoat ${ }^{\circledR}$ coated pellets was in adherence with the drug release (Figure 2B).

The unchanged swelling of both uncured and cured Aquacoat ${ }^{\circledR}$ ECD coated pellets was also supported by observing no visible change in macroscopic pictures of the uncured and cured pellets after drug release (Figure 4). In contrast, the Eudragit ${ }^{\circledR} \mathrm{NE} 30 \mathrm{D}$ coated cured pellets revealed increased water uptake and swelling in comparison to the uncured ones (Figure 2D, 2F), which could also be confirmed from the macroscopic pictures after drug release of the uncured and cured pellets wherein a noticeable increase in pellet size was seen after curing (Figure 5). However, the weight loss of uncured and cured Eudragit ${ }^{\circledR}$ NE 30D coated pellets was in connection with released drug. For instance, the higher weight loss of uncured pellet was balanced by faster drug release and vice versa (Figure 3E)

Moreover, the video monitoring during dissolution of the uncured and cured Aquacoat ${ }^{\mathbb{B}}$ ECD coated pellets did not provide any notable difference in the swelling behavior (Figure 4A-F).

In comparison, the Eudragit ${ }^{\circledR} \mathrm{NE}$ 30D coated uncured and cured pellets revealed entirely disparate swelling behavior during video monitoring. In the case of uncured pellets, localized swelling of the coating was observed whereas the coating of cured pellets was uniformly and extensively swollen, as a result, the cured pellets were significantly larger in size when compared to the uncured pellets (Figure 5A-F) (Irfan et al., 2009; Irfan et al., 2017; Dashevsky et al., 2010).

With respect the adhesive force of the coating, determined using model tablets, it was found that to Aquacoat ${ }^{\circledR}$ ECD coatings was not significantly altered after curing (Figure 6A) and, after taken out of the stability chamber $\left(60{ }^{\circ} \mathrm{C}-75 \% \mathrm{RH}\right)$, they were not sticky and wet upon feeling. However, the adhesive force of Eudragit ${ }^{\circledR}$ NE 30D coatings was decreased upon curing (Figure 6B), and interestingly, they were sticky and wet when taken out of stability chamber at $60{ }^{\circ} \mathrm{C}-75 \% \mathrm{RH}$. The decreased adhesive force of Eudragit ${ }^{\circledR}$ NE 30D coating could be due to breaking of interfacial bonding caused by water penetration through to the coatings and also by changed swelling coefficient of core and coating (Felton, McGinity, 1999; Irfan et al., 2009; Irfan et al., 2017). This could also be the reason for extensive uniform swelling of cured Eudagit ${ }^{\circledR}$ NE 30D coated pellets.

Differences in behavior in the dissolution tests observed between the two polymers can be attributed to differences in their mechanical properties. Aquacoat ${ }^{\mathbb{R}}$ ECD produces better coalescence of the particles and formation of more cohesive and stable films, even after storage under drastic conditions; on the other hand, films obtained with Eurdagit ${ }^{\circledR}$ NE 30D presented a reduction of adhesive strength to the nuclei, with swelling, both for cured and uncured pellets, and consequent increase in the release time (Irfan et al., 2017). 


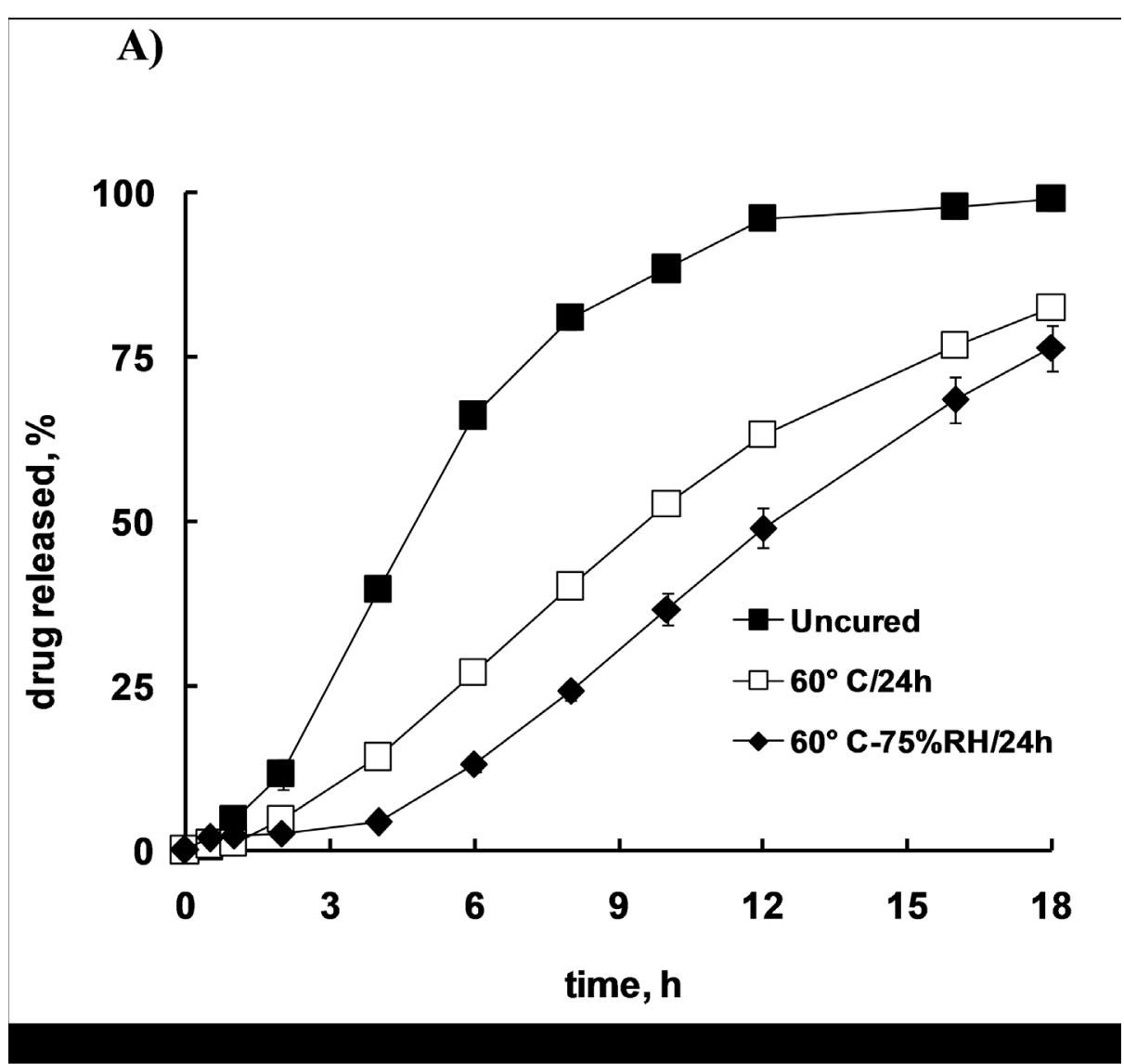

B)

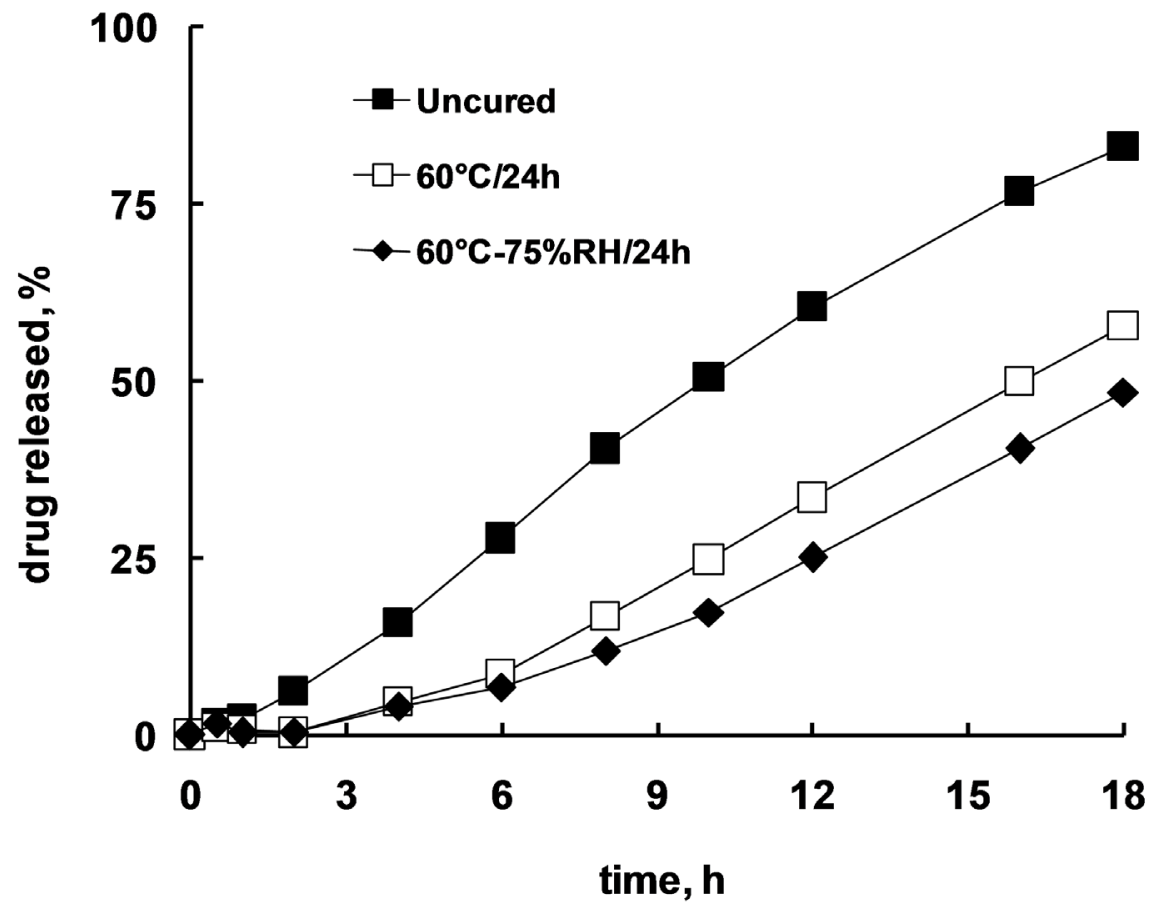

FIGURE 1 - Effect of curing on drug release from pellets based on sugar cores loaded with $10 \%$ proranolol $\mathrm{HCl}$ and coated with: A) Aquacoat ${ }^{\circledR}$ ECD using TEC $25 \%$ and Talc 35\%, B) Eudragit ${ }^{\circledR}$ NE 30D using Talc 35\%, coating level 20\%. 


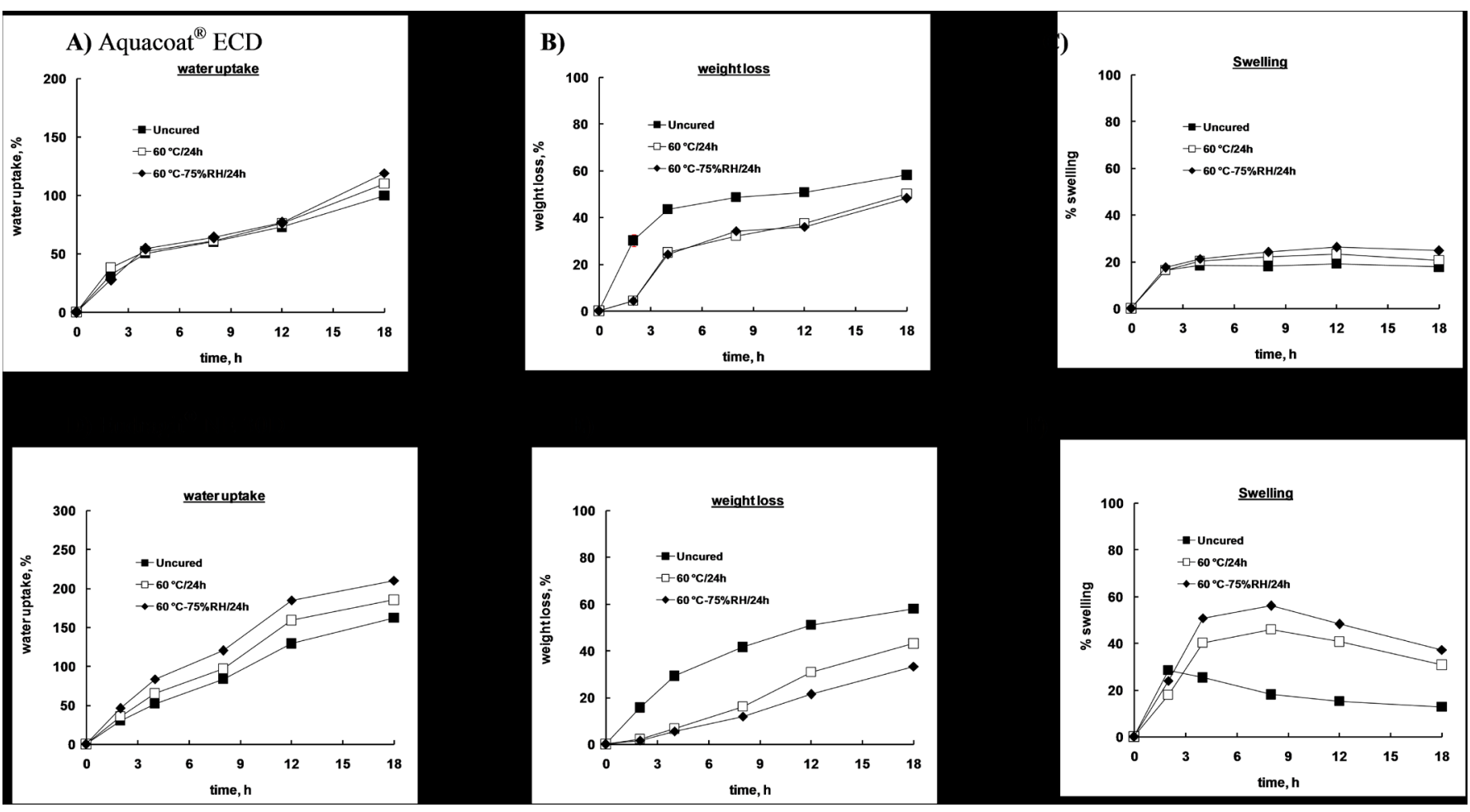

FIGURE 2 - Water uptake-weight loss and swelling of uncured and cured pellets as a function of time in $0.01 \mathrm{~N} \mathrm{HCl} \mathrm{based} \mathrm{on}$ sugar cores loaded with $10 \%$ propranolol $\mathrm{HCl}$ and coated with: A-C) Aquacoat ${ }^{\circledR}$ ECD and D-F) Eudragit ${ }^{\circledR}$ NE $30 \mathrm{D}$, coating level $20 \%$.

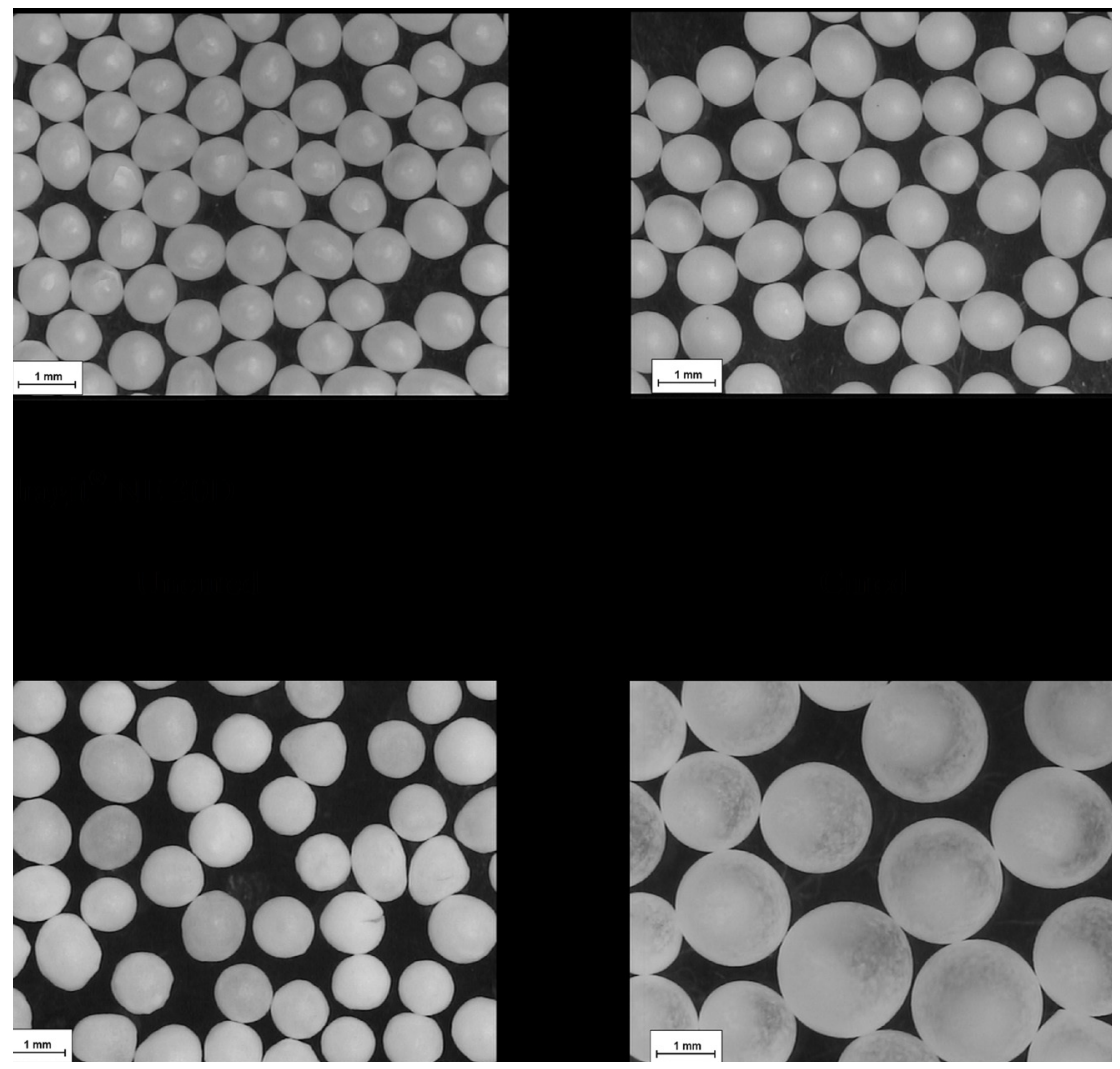

FIGURE 3 - Macroscopic pictures of uncured and cured $\left(60^{\circ} \mathrm{C} / 75 \% \mathrm{RH} / 24 \mathrm{~h}\right)$ coated pellets based on sugar cores loaded with $10 \%$ propranolol $\mathrm{HCl}$ after drug release in $0.01 \mathrm{~N} \mathrm{HCl}$ : A) Aquacoat ${ }^{\circledR}$ ECD and B) Eudragit ${ }^{\circledR} \mathrm{NE}$ 30D. 

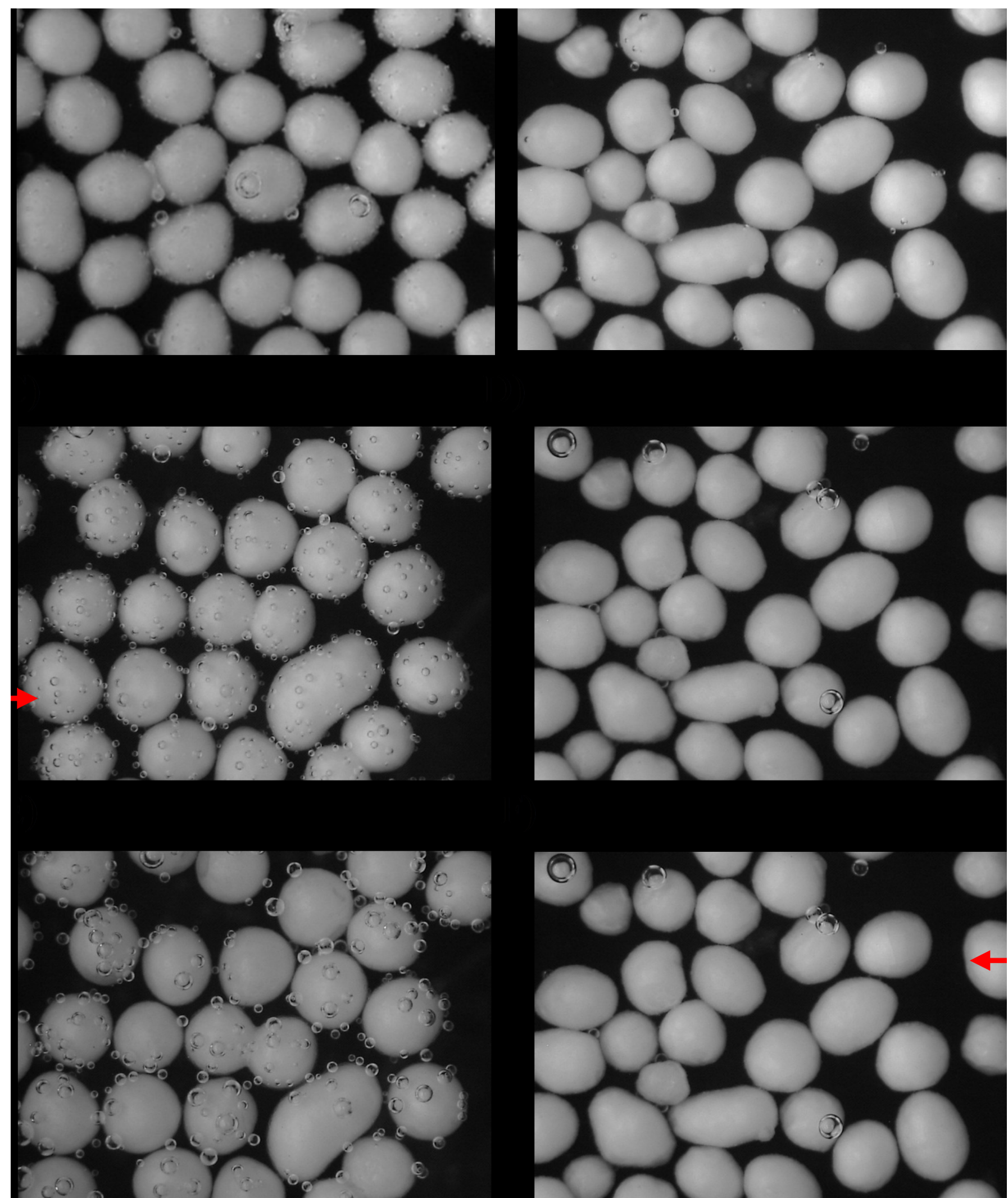

FIGURE 4 - Macroscopic pictures of uncured and cured $\left(60{ }^{\circ} \mathrm{C} / 75 \% \mathrm{RH} / 24 \mathrm{~h}\right)$ pellets based on sugar cores loaded with $10 \%$ propranolol $\mathrm{HCl}$ coated with Aquacoat ${ }^{\mathbb{R}} \mathrm{ECD}$ using talc $35 \%$ as a function of time in $0.01 \mathrm{~N} \mathrm{HCl}$. 

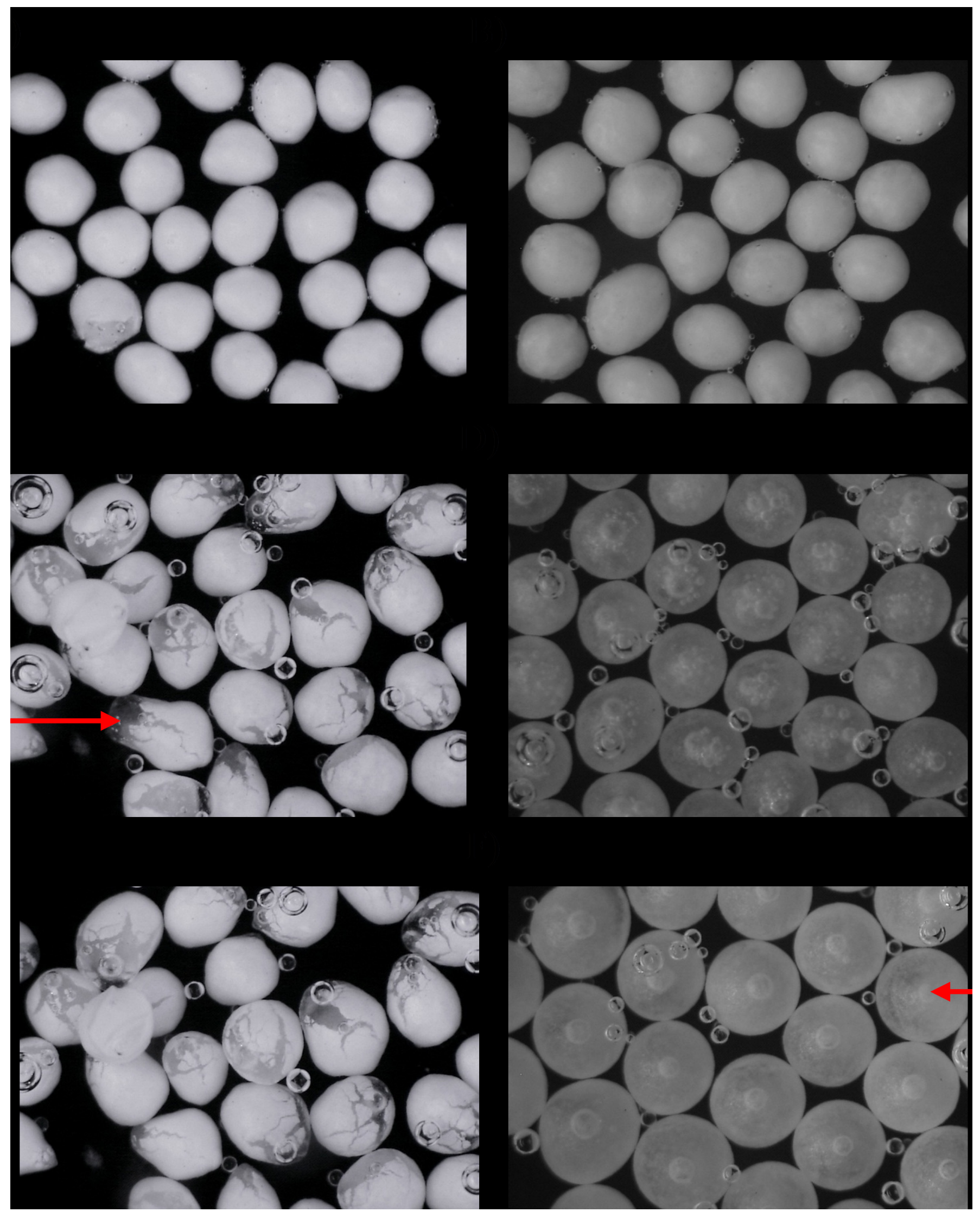

FIGURE 5 - Macroscopic pictures of uncured and cured $\left(60{ }^{\circ} \mathrm{C} / 75 \% \mathrm{RH} / 24 \mathrm{~h}\right)$ pellets based on sugar cores loaded with $10 \%$ propranolol $\mathrm{HCl}$ coated with Eudragit ${ }^{\circledR} \mathrm{NE}$ 30D using $35 \%$ talc as a function of time in $0.01 \mathrm{~N} \mathrm{HCl}$. 

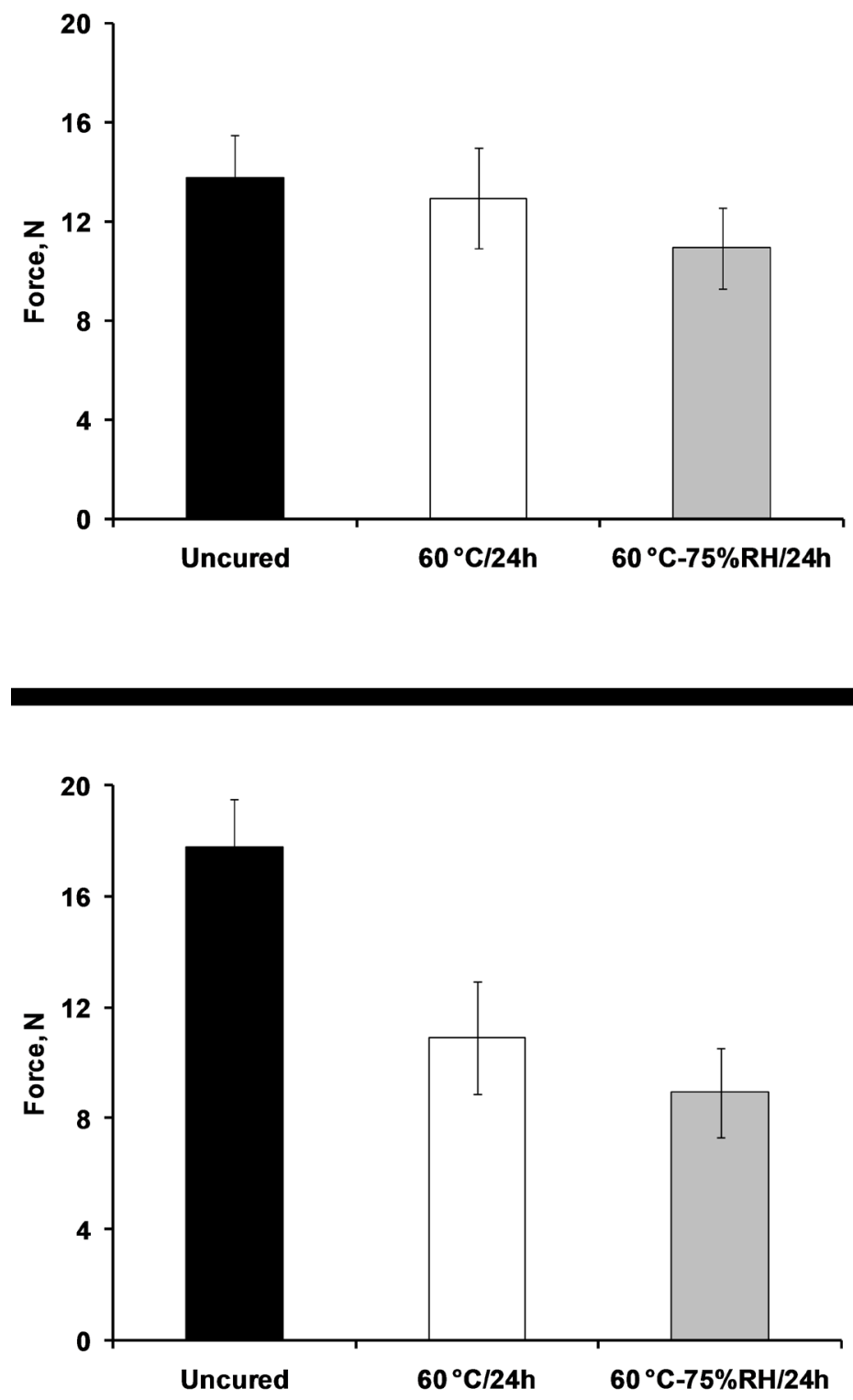

FIGURE 6 - Effect of curing on adhesive force of polymeric coatings to the drug-layered-cores using model tablets (drug layered and polymer coated like pellets): A) Aquacoat ${ }^{\circledR}$ ECD and B) Eudragit ${ }^{\circledR}$ NE 30D, coating level $20 \%$.

To overcome curing effect associated with individual Auacoat ${ }^{\circledR}$ ECD and Eudrgait ${ }^{\circledR}$ NE 30D coatings, a new approach using blend of Eudragit ${ }^{\circledR}$ $\mathrm{NE} 30 \mathrm{D}$ and Aquacoat ${ }^{\circledR}$ ECD in various ratios was further investigated. The results revealed that the drug was released quickly when 5:95 (Eudragit $^{\circledR} \mathrm{NE} 30 \mathrm{D}$ : Aquacoat ${ }^{\circledR}$ ECD) blend was used, however, by increasing the Eudragit ${ }^{\circledR}$ NE 30D concentration to 25:75 (Eudragit ${ }^{\circledR}$ NE 30D: Aquacoat $\left.{ }^{\circledR} E C D\right)$, the drug was released in a controlled way following sigmoidal shape of curve (Figure 7). No significant change in drug release pattern was noticed when Eudragit ${ }^{\circledR}$ NE 30D concentration was further increased to 40:60 (Eudragit $^{\circledR}$ NE 30D: Aquacoat $\left.t^{\circledR} E C D\right)$. Therefore, in order to elucidate curing effect, the blend of Eudragit ${ }^{\circledR}$ NE 30D: Aquacoat ${ }^{\circledR}$ ECD in 25:75 ratio was used for further studies.

Figure 8 shows drug release from pellets coated using Eudrgait ${ }^{\circledR}$ NE 30D: Aqucoat ${ }^{\circledR}$ ECD (25:75) at different coating levels; the drug release was decreased as a function of increasing coating level.

The water uptake-weight loss as well as swelling of the uncured and cured pellets were almost similar (Figure 10A-C). 


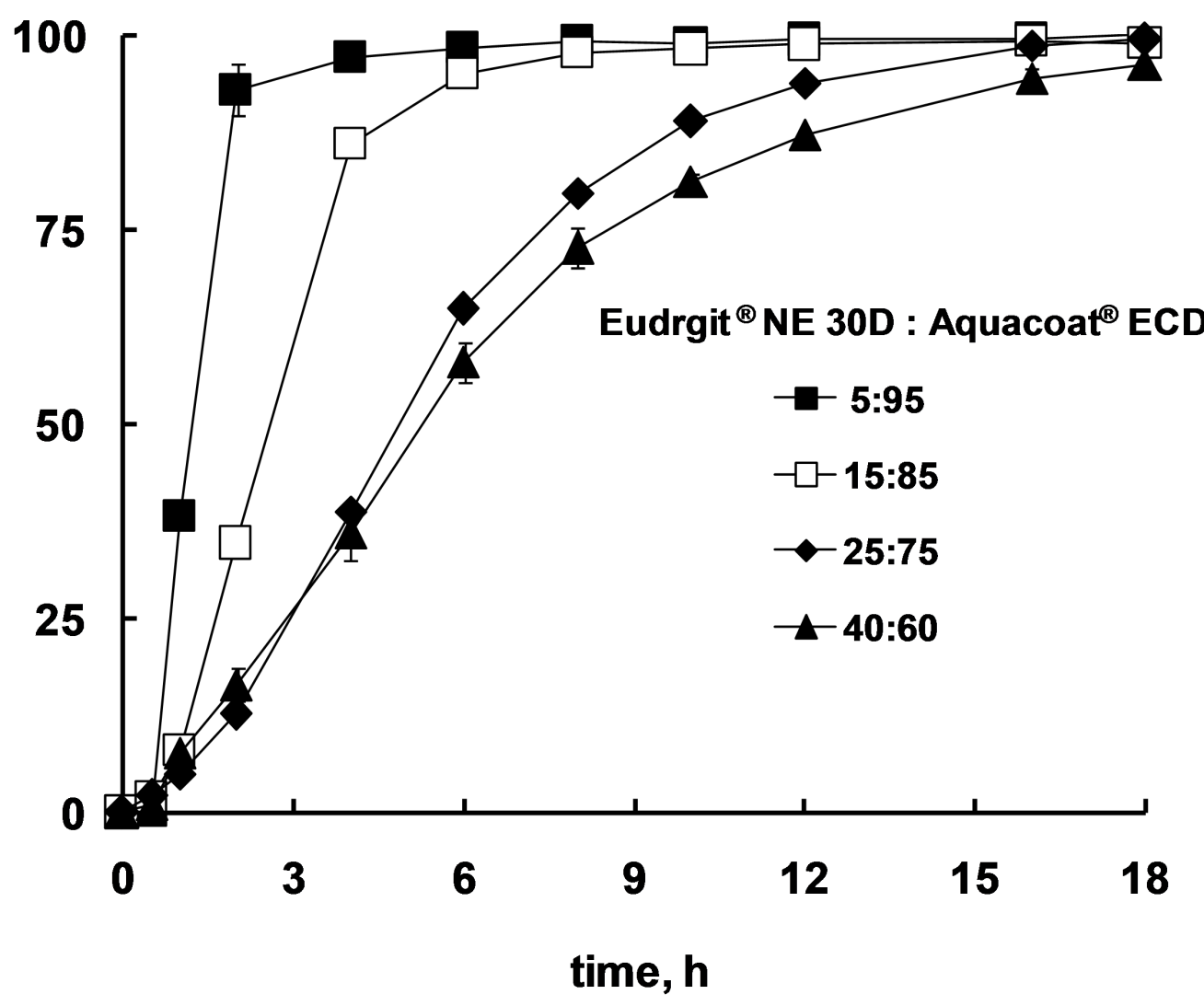

FIGURE 7 - Drug release from pellets based on sugar cores loaded with 10\% propranolol $\mathrm{HCl}$ and coated with different polymer blend ratios of Eudragit ${ }^{\circledR}$ NE 30D: Aquacoat ${ }^{\circledR}$ ECD using 35\% talc, coating level $20 \%$.

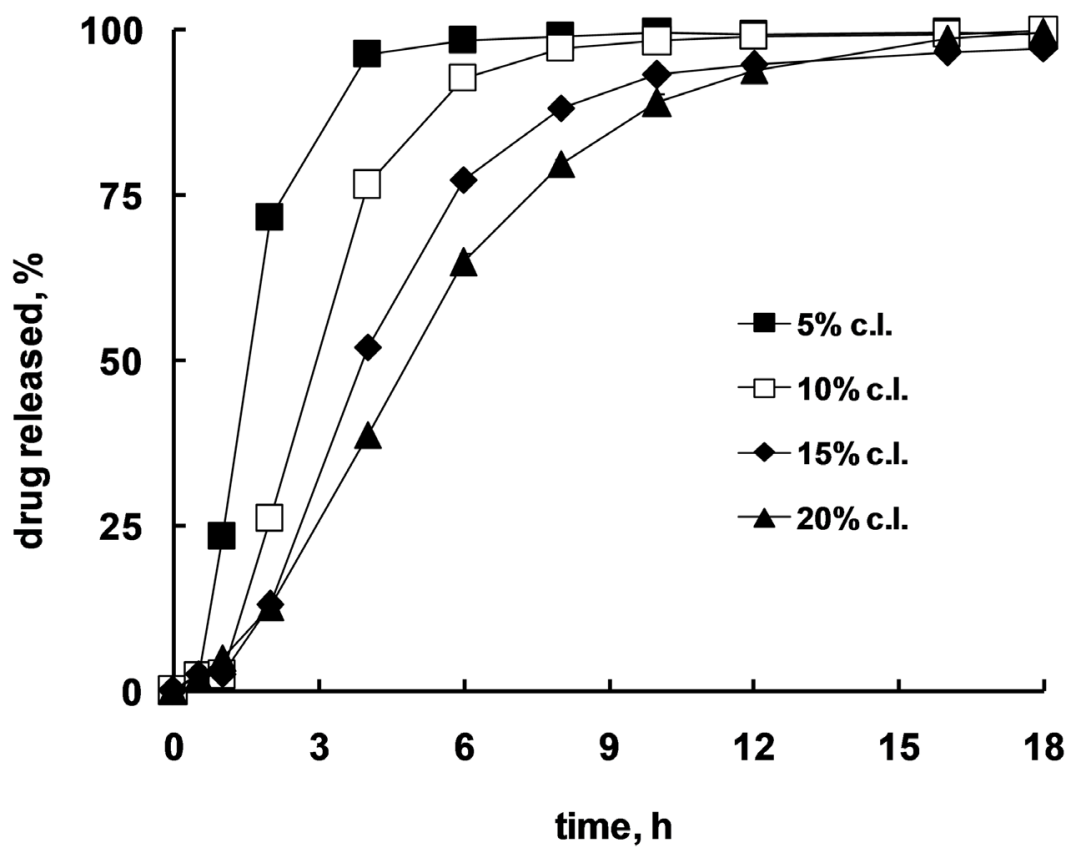

FIGURE 8 - Effect of coating levels on drug release from pellets based on sugar cores loaded with $10 \%$ propranolol $\mathrm{HCl}$ and coated with a polymer blend of Eudragit ${ }^{\circledR}$ NE 30D: Aquacoat ${ }^{\circledR}$ ECD (25:75) using 35\% talc. 
The release profile was maintained even after storage under drastic conditions of temperature and humidity (Figure 9).

The video monitoring during dissolution of the uncured and cured pellets revealed the similar swelling behavior with uniform increase in size without local swelling (Figure 11A-D).

The adhesive force of the coating to the druglayered-cores was not affected upon curing at elevated temperature and humidity $\left(60{ }^{\circ} \mathrm{C}-75 \% \mathrm{RH}\right)$ (Figure 12).

The pellets coated with Eudrgait ${ }^{\circledR}$ NE 30D: Aqucoat ${ }^{\circledR}$ ECD (25:75) with no curing effect remained stable at $40{ }^{\circ} \mathrm{C}$ and $40{ }^{\circ} \mathrm{C}-75 \% \mathrm{RH}$ up to 3 months (Figure 13A-B).

The results allow us to infer that blend of Eudrgait ${ }^{\mathbb{R}}$ NE 30D: Aqucoat ${ }^{\circledR}$ ECD not only compensated the poor film formation, but also prevented the decrease in adhesive force observed to Eudrgait ${ }^{\circledR}$ NE 30D coatings. Probably, the addition of Eudrgait ${ }^{\circledR}$ NE 30D, with low Tg $\left(-8{ }^{\circ} \mathrm{C}\right)$, plasticized the Aqucoat ${ }^{\circledR}$ ECD to some extent, reducing its $\mathrm{Tg}$ from $135^{\circ} \mathrm{C}$ to $123{ }^{\circ} \mathrm{C}$ (Table I) (Zheng, McGinity, 2003).

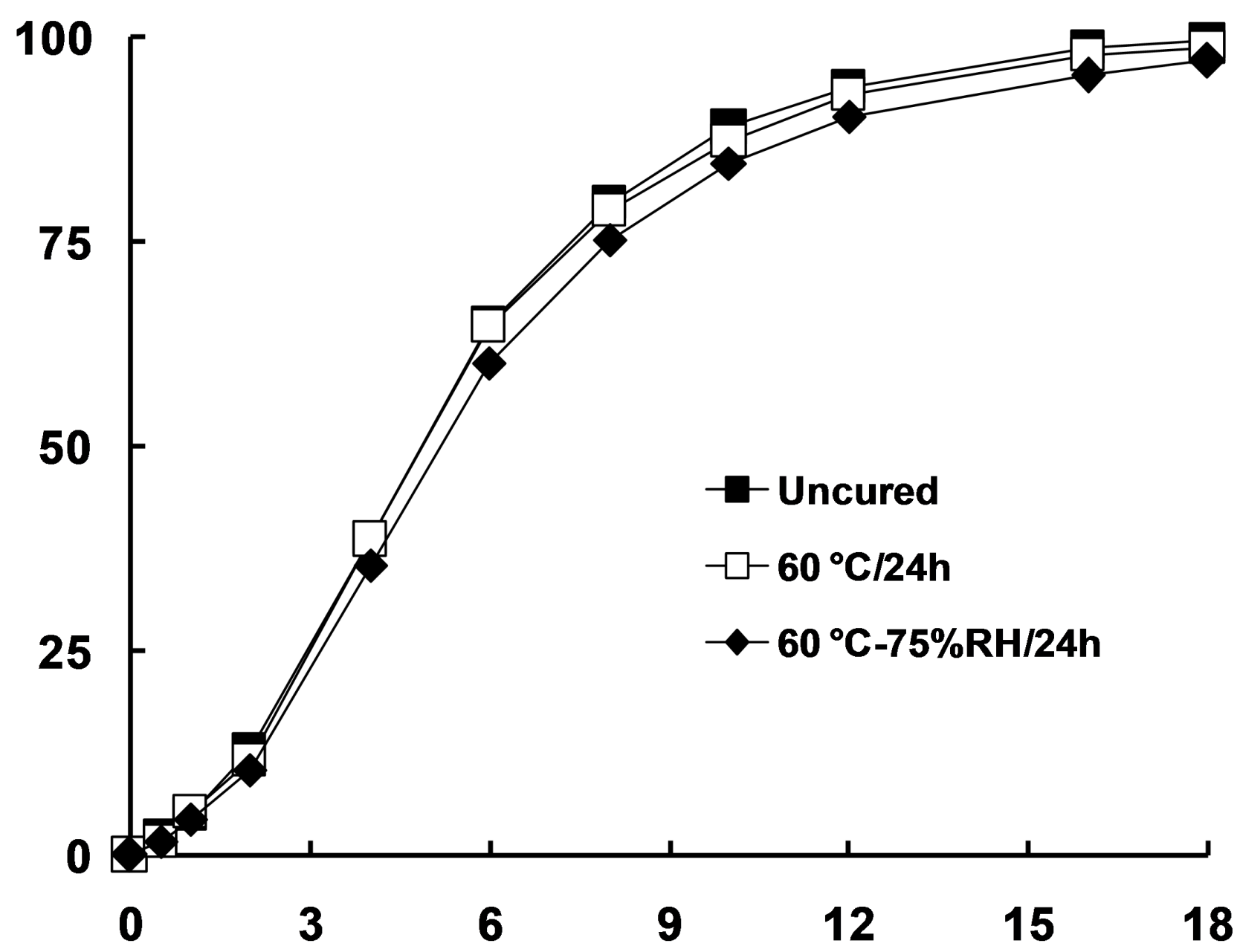

FIGURE 9 - Effect of curing on drug release from pellets based on sugar cores loaded with 10\% proranolol $\mathrm{HCl}$ and coated with a polymer blend of Eudragit ${ }^{\circledR}$ NE 30D: Aquacoat ${ }^{\circledR}$ ECD (25:75) using 35\% talc, coating level $20 \%$. 

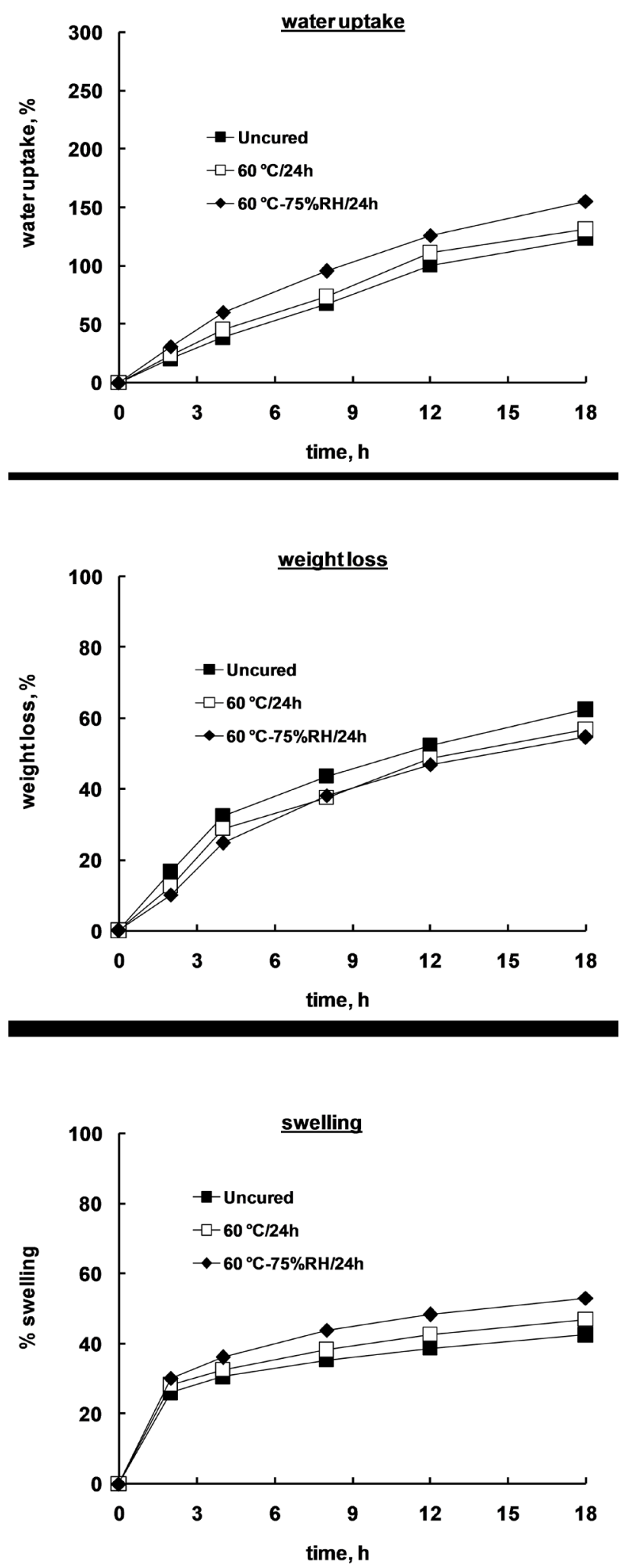

FIGURE 10 - Water uptake-weight loss and swelling of uncured and cured pellets as a function of time in $0.01 \mathrm{~N} \mathrm{HCl}$ based on sugar cores loaded with $10 \%$ propranolol $\mathrm{HCl}$ and coated with a polymer blend of Eudragit ${ }^{\circledR} \mathrm{NE}$ 30D: Aquacoat ${ }^{\circledR}$ ECD (25:75) using $35 \%$ talc, coating level $20 \%$. 
Uncured

A)

$0 \mathrm{~h}$

$2 \mathrm{~h}$

Low uniform swelling

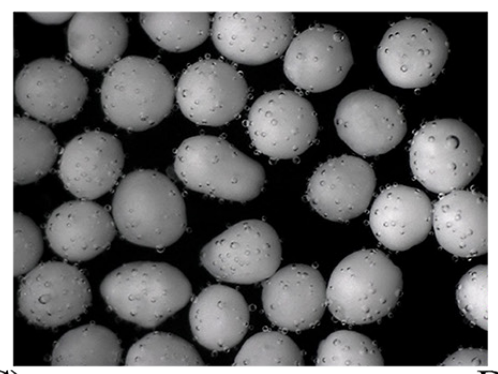

C)

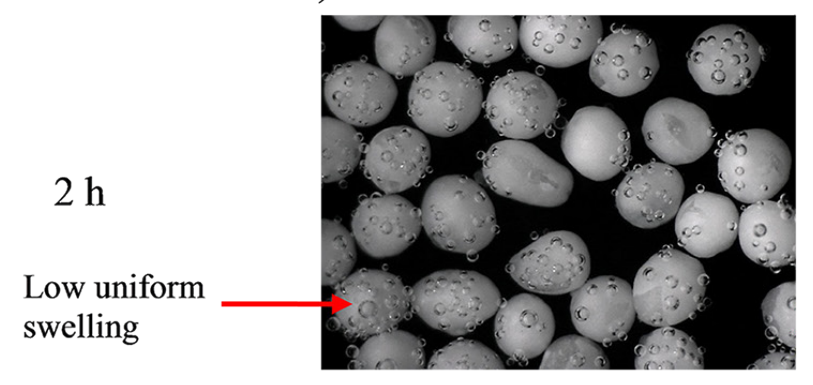

E)

$6 \mathrm{~h}$

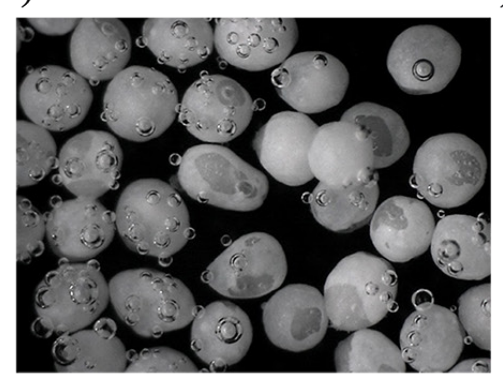

B)

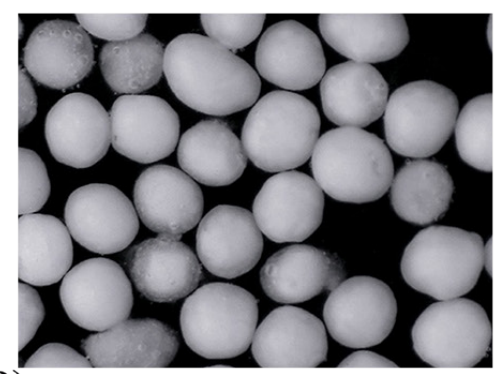

D)

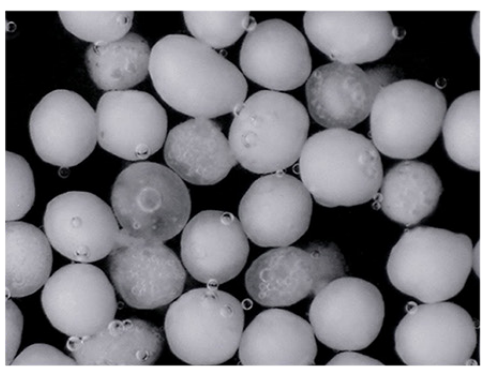

F)

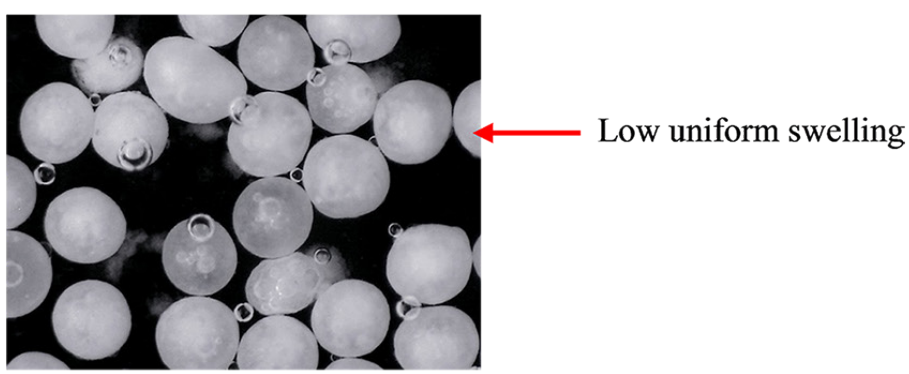

FIGURE 11 - Macroscopic pictures of uncured and cured $\left(60{ }^{\circ} \mathrm{C} / 75 \% \mathrm{RH} / 24 \mathrm{~h}\right)$ pellets based on sugar cores loaded with $10 \%$ propranolol $\mathrm{HCl}$ coated with Eudragit ${ }^{\circledR} \mathrm{NE}$ 30D: Aquacoat ${ }^{\circledR} \mathrm{ECD}(25: 75)$ using $35 \%$ talc as a function of time in $0.01 \mathrm{~N} \mathrm{HCl}$. 


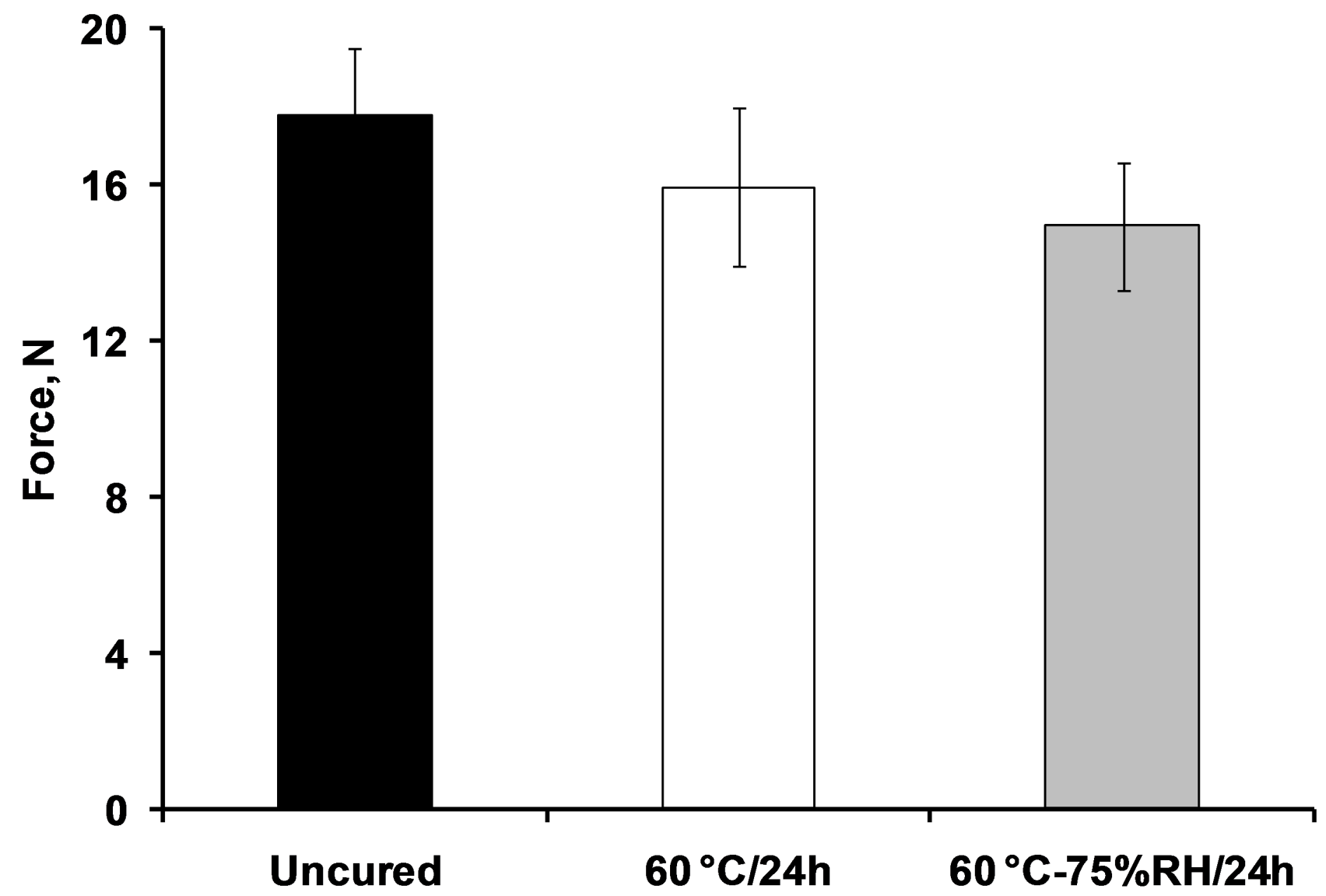

FIGURE 12 - Effect of curing on adhesive force of Eudragit ${ }^{\circledR}$ NE 30D: Aquacoat ${ }^{\circledR}$ ECD (25:75) polymeric coatings to the druglayered-cores using model tablets (drug layered and polymer coated like pellets), coating level $20 \%$. 

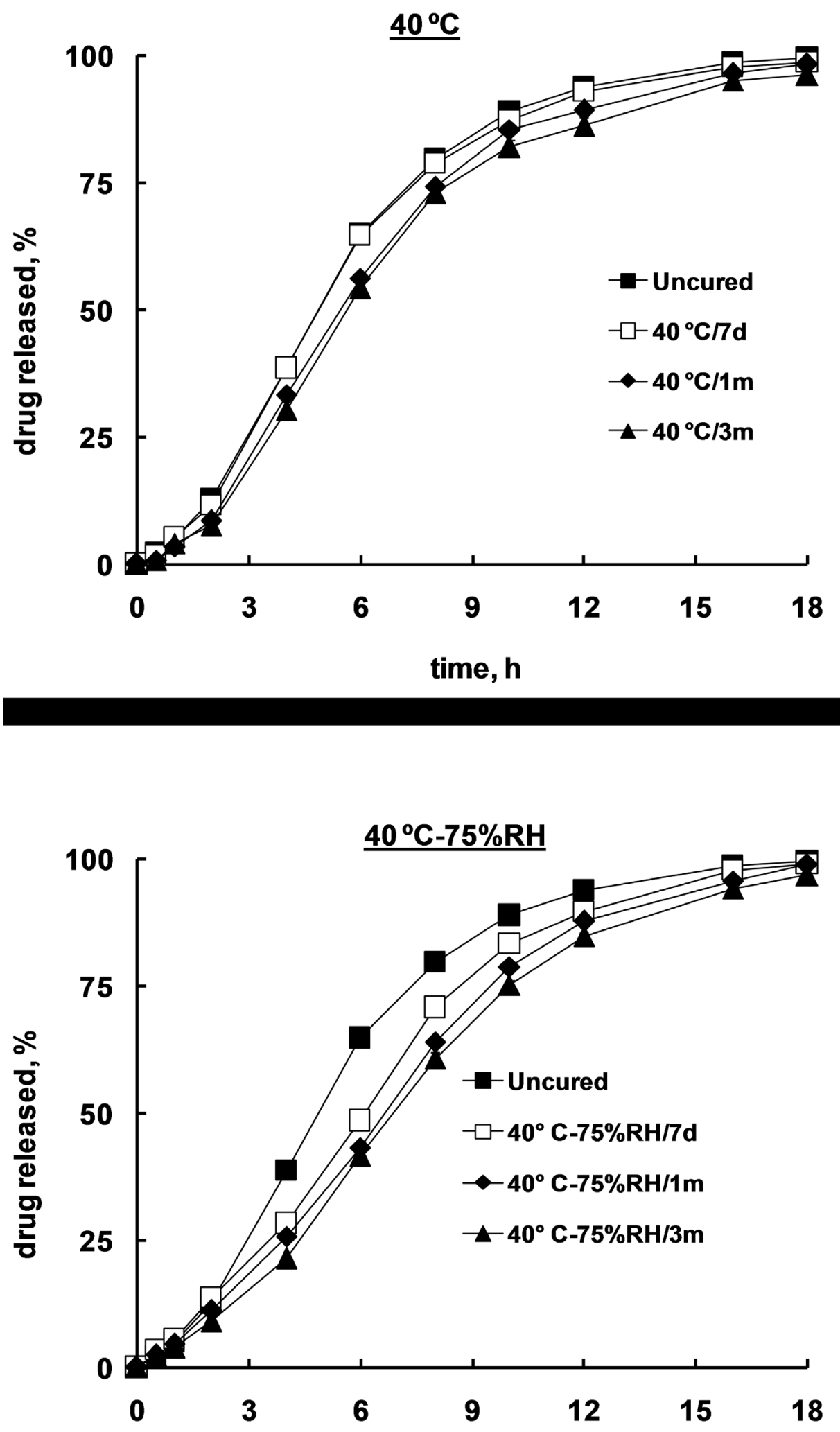

FIGURE 13 - Effect of accelerated storage conditions on the stability of propranolol $\mathrm{HCl}$ release from pellets based on sugar cores with $10 \%$ drug loading and coated with a polymer blend of Eudragit ${ }^{\circledR}$ NE 30D: Aquacoat ${ }^{\circledR}$ ECD (25:75) using 35\% talc, coating level $20 \%$. 
TABLE I - Glass transition temperature $\left(T_{g}\right)$ of Eudragit ${ }^{\circledR}$ NE 30D, Aquacoat ${ }^{\circledR}$ ECD and blend of Eudragit ${ }^{\circledR}$ NE 30D: Aquacoat ${ }^{\circledR}$ $\operatorname{ECD}(75: 25)$

\section{Polymer}

Eudragit $^{\circledR}$ NE 30D

Aquacoat ${ }^{\circledR} \mathrm{ECD}$

Eudragit ${ }^{\circledR}$ NE 30D: Aquacoat ${ }^{\circledR}$ ECD $(25: 75)$
Glass Transition Temperature $\left(\mathrm{T}_{\mathrm{g}}\right),{ }^{\circ} \mathrm{C}$

125

\section{CONCLUSION}

A strong curing effect (decrease in drug release) was observed with pellets coated with individual Eudragit $^{\circledR}$ NE 30D and Aquacoat ${ }^{\circledR}$ ECD, depicting entirely different curing mechanisms. According to the found curing mechanisms; Aquacoat ${ }^{\circledR}$ ECD coated pellets showed curing effect probably due to further gradual coalescence of polymeric particles upon storage at elevated temperature and humidity which resulted into better film formation, ultimately, decreasing the drug release. In contrast, the curing effect of Eudragit ${ }^{\circledR}$ NE 30D coated pellets was caused by decrease in adhesive force of coatings to the drug-layered-cores after treatment at elevated temperature and humidity providing a completely different swelling behavior of uncured (localized swelling) and cured (uniform swelling) pellets. The curing effect was eliminated using their blends in appropriate ratio, compensated the main irregularities associated with these individual polymers (Aquacoat $^{\circledR}$ ECD - further gradual coalescence and Eudragit ${ }^{\circledR}$ NE 30D - decreased adhesive force of coating.

\section{REFERENCES}

Cuppoka Y, Muscherta S, Marucci M, Hjaertstam J, Siepmanna F, Axelsson A, et al. Drug release mechanisms from Kollicoat SR:Eudragit NE coated pellets. Int J Pharm. 2011;409(1-2):30-37.

Dashevsky A, Wagner K, Kolter K, Bodmeier R. Physicochemical and release properties of pellets coated with Kollicoat SR 30D, a new aqueous polyvinyl acetate dispersion for extended release. Int J Pharm. 2005;290(1-2):15-23.
Dashevsky A, Kolter K, Bodmeier R. pH-independent release of a basic drug from pellets coated with the extended release polymer dispersion Kollicoat SR 30 D and the enteric polymer dispersion Kollicoat MAE 30DP. Eur J Pharm Biopharm. 2004;58(1):45-49.

Dashevsky A, Ahmed AR, Mota J, Irfan M, Kolter K, Bodmeier R. Effect of water- soluble polymers on the physical stability of aqueous polymeric dispersions and their implications on the drug release from coated pellets. Drug Dev Ind Pharm. 2010;36(2):152-60.

El-Malah Y, Nazzal S. Novel use of Eudragit ${ }^{\circledR}$ NE 30D/ Eudragit $^{\circledR}$ L 30D-55 blends as functional coating materials in time-delayed drug release applications. Int J Pharm. 2008;357(1-2):219-227.

Felton LA, McGinity JW. Adhesion of polymeric films to pharmaceutical solids. Eur J Pharm Biopharm. 1999;47(1):3-14.

Fukumori Y, Coating of multiparticulates using polymeric dispersions. In: Ghebre-Sellassie I, editor. Multiparticulate Oral Drug Delivery. New York: Marcel Dekker Inc; 1997. p.79-111.

Hudovornik G, Vrecer F. Impact of the curing parameters on drug release from Eudragit RS and RL 30D coated pellets: Design of experiments. J Drug Del Sci Tech. 2015;30(Part A):146-153.

Ho L, Cuppok Y, Muschert S, Gordone KC, Pepper M, Shen $\mathrm{Y}$, et al. Effects of film coating thickness and drug layer uniformity on in vitro drug release from sustained-release coated pellets: A case study using terahertz pulsed imaging. Int J Pharm. 2009;382(1-2):151-159.

Irfan M, Ahmed AR, Dashevsky A, Kolter K, Bodmeier R. Formulation parameters affecting the adhesion of Kollicoat ${ }^{\mathbb{B}}$ SR 30D coatings to the drug layer in coated pellets and their 
Polymer blend: a new approach for eliminating curing effect of aqueous dispersion coatings

implications on curing phenomena. Paper presented at: $36^{\text {th }}$ Annual CRS Meeting and Exposition 2009; Copenhagen, Denmark.

Irfan M, Ahmed AR, Kolter K, Bodmeier R, Dashevskiy A. Curing mechanism of flexible aqueous polymeric coatings. Eur J Pharm Biopharm. 2017;115:186-196.

Kolter K, Dashevsky A, Irfan M, Bodmeier R. Polyvinyl acetate-based film coatings. Int J Pharm. 2013;457(2):470-479.

Kranza H, Gutsche S. Evaluation of the drug release patterns and long term stability of aqueous and organic coated pellets by using blend of enteric and gastrointestinal insoluble polymers. Int J Pharm. 2009;380(1-2):112-119.

Kucera S, Tessmann C, Shah NH, Malick AW, Infeld MH, McGinity, JW. The influence of ethylcellulose polymers on the physical stability of theophylline pellets coated with Eudragit NE 30D. J Drug Del Sci Tech. 2008;18(5):343-349.

Lecomte F, Siepmann J, Walther M, MacRae RJ, Bodmeier R. $\mathrm{pH}$ sensitive polymer blends used as coating materials to control drug release from spherical beads: elucidation of the underlying mass transport mechanisms. Pharm Res. 2005;22(7):1129-1141.

McGinity JW, Linda FA. Aqueous Polymeric Coatings for Pharmaceutical Dosage Forms. $3^{\text {rd }}$ edition. New York, USA: Marcel Dekker publishing; 1997.

Muschert S, Siepmann F, Leclercq B, Carlin B, Siepmann J. Prediction of drug release from ethylcellulose coated pellets. J Control Release. 2009a;135(1):71-79.
Muschert S, Siepmann F, Cuppok Y, Leclercq B, Carlin B, Siepmann J. Improved long term stability of aqueous ethylcellulose film coatings: Importance of the type of drug and starter core. Int J Pharm. 2009b;368(1-2):138-145.

Siepmann F, Muschert S, Leclercq B, Carlin B, Siepmann, J. How to improve the storage stability of aqueous polymeric film coatings. J Control Release. 2007;126(1):26-33.

Siepmann F, Siepmann J, Walther M, MacRae RJ, Bodmeier R. Blends of aqueous polymer dispersions used for pellet coating: Importance of the particle size. J Control Release. 2005;105(3):226-239.

Siepmann F, Siepmann J, Walther M, MacRae RJ, Bodmeier R. Polymer blends for controlled release coatings. J Control Release. 2008;125(1):1-15.

Shao ZJ, Morales L, Diaz S, Muhammad NA. Drug release from Kollicoat SR 30D-coated nonpareil beads: Evaluation of coating level, plasticizer type, and curing condition. AAPS PharmSciTech. 2002;3(2):E15.

Strübing S, Metz H, Mäder K. Mechanistic analysis of drug release from tablets with membrane controlled drug delivery. Eur J Pharm Biopharm. 2007;66(1):113-119.

Zheng W, McGinity JW. Influence of Eudragit NE 30 D blended with Eudragit L 30 D-55 on the release of phenylpropanolamine hydrochloride from coated pellets. Drug Dev Ind Pharm. 2003;29(3):357-366.

Received for publication on $16^{\text {th }}$ August 2018 Accepted for publication on $01^{\text {st }}$ February 2019 